\title{
Studi Retrospektif Penggunaan Obat Dan Potensi Interaksi Obat Pasien Systemic
} Lupus Erythematosus

\section{A Retrospective Study of Drug Used and Potential Drug Interactions in Patients with Systemic Lupus Erythematosus}

\author{
Siluh Putu Astini ${ }^{1}$, Ni Nyoman Wahyu Udayani ${ }^{1}$, Herleeyana MeriyanI ${ }^{1 \bullet}$ \\ ${ }^{1}$ Fakultas Farmasi Universitas Mahasarawati Denpasar, \\ Jalan Kamboja No.11A, Denpasar, Bali
}

\begin{abstract}
Abstrak: Systemic Lupus Erythematosus (SLE) merupakan penyakit autoimun kompleks yang melibatkan beberapa sistem tubuh dengan gambaran manifestasi klinis, perjalanan penyakit, dan prognosis beragam. Kompleksitas pengobatan dan munculnya masalah terkait obat, menuntut peran farmasis yang lebih besar dalam melakukan pharmaceutical care. Tujuan dari penelitian ini adalah untuk mengetahui pola peresepan dan mengidentifikasi adanya potensi interaksi obat pada pasien SLE di Instalasi Rawat Jalan di salah satu rumah sakit di Kota Denpasar. Penelitian ini merupakan penelitian retrospektif dan observasional. Penelitian menggunakan data sekunder berupa catatan rekam medis pasien SLE yang menjalani rawat jalan di Poliklinik Penyakit Dalam Instalasi Rawat Jalan Rumah Sakit Umum Pusat Sanglah periode Januari-Desember 2019. Pasien SLE yang menjadi sampel dalam penelitian ini berjumlah 210 orang yang terdiri atas $12,86 \%$ laki-laki dan $87,14 \%$ perempuan. Sebanyak $29,05 \%$ pasien berada pada usia remaja yaitu 17-25 tahun. Penggunaan obat imunosupresan terbanyak yaitu metilprednisolon (48,93\%), analgesik terbanyak parasetamol (88,46\%). Potensi interaksi mayor terjadi pada $12,10 \%$ pasien, sedangkan potensi interaksi sedang $80,40 \%$ dan potensi interaksi minor sebesar 7,5\%.
\end{abstract}

Kata Kunci: penggunaan obat, potensi interaksi obat, SLE.

\begin{abstract}
Systemic Lupus Erythematosus is a complex autoimmune disease involving multiple organs with various clinical manifestations and prognosis. The complexity of treatment and the emergence of drug related problems, demands a greater role of pharmacy in conducting pharmaceutical care. The aim of this study was to explore drug used and to identify potential drug interactions in SLE outpatient at one hospital in Denpasar. This study was a retrospective and observational study collection. The study used secondary data in medical record during January-December 2019. There were 210 SLE people consisted of $12.86 \%$ males and $87.14 \%$ women. $29.05 \%$ of the patients aged $17-25$ years. The most immunosuppressants used was methylprednisolone $(48.93 \%)$, the most analgetic used was acetaminophen (88.46\%). $12.10 \%$ of patients had a potential serious drug interaction, $80.40 \%$ had a moderate and $7.5 \%$ had minor drug interaction.

Keywords: drug use, potential drug interactions, SLE.
\end{abstract}

\section{PENDAHULUAN}

$$
\text { Systemic lupus erythematosus }
$$

merupakan penyakit inflamasi autoimun heterogen kronis dengan etiologi yang belum diketahui, manifestasi klinis, perjalanan penyakit yang beragam serta melibatkan banyak organ berbeda, serta diikuti dengan adanya sebuah perjalanan klinis yang bervariasi (Kuhn et al., 2015; Perhimpunan Reumatologi Indonesia, 2019; Touma \& Gladman,
2017). Systemic lupus erythematosus (SLE) sering dikenal dengan penyakit seribu wajah, dengan perjalanan penyakit yang sangat dinamis sehingga sering menyulitkan penegakan diagnosis ketika terdapat gejala atau keluhan yang tidak lengkap. Secara global prevalensi SLE diperkirakan lebih dari 150 kasus/ 100.000 penduduk dengan insiden ratarata 1-10/ 100.000 orang/ tahun dengan mayoritas

•email korespondensi: herleeyana.m@unmas.ac.id 
penderita SLE adalah wanita (90\%) (Touma \& Gladman, 2017).

Pada tahun 2012 diketahui secara global bahwa 56 juta orang meninggal karena penyakit tidak menular dengan kejadian paling tinggi disebabkan oleh SLE (Kementerian Kesehatan Republik Indonesia, 2017). Incidence rate SLE di seluruh dunia adalah sekitar 1 hingga 10 per 100.000 orang/tahun dan prevalensi diperkirakan melebihi 300.000 orang (Cunha \& Gilek-Seibert, 2016). Di Indonesia, prevalensi kejadian penyakit SLE adalah diperkirakan 1 kasus per 2.000 populasi dengan insiden 1 kasus per 10.000 populasi (Yayasan Lupus Indonesia, 2011). Berdasarkan data Dinas Kesehatan Provinsi Bali, terdapat 25 kasus SLE yang terjadi pada tahun 2012. Data terakhir pada tahun 2013 menunjukkan peningkatan jumlah kasus SLE mencapai 75 kasus.

Penanganan SLE melibatkan penggunaan imunosupresan dan kortikosteroid. Selain itu agen sitotoksik seperti siklofosfamid dan azaioprin tidak jarang digunakan dalam terapi SLE. Terapi SLE dengan obat-obat tersebut berpotensi menimbulkan adverse drug reaction yang mengakibatkan penurunan kualitas hidup pasien SLE (Kamal \& Jusko, 2014). Potensi interaksi obat yang cukup tinggi pada pasien SLE yang menggunakan kortokosteroid dan agen immunosupresan serta obat lain yang mungkin digunakan oleh pasien SLE perlu diwaspadai (Kamal \& Jusko, 2014).

Pengobatan dan perawatan yang tepat dan benar sangat dibutuhkan oleh penderita SLE, yang bertujuan untuk mengatasi gejala dan induksi remisi serta mempertahankan remisi selama mungkin pada perkembangan penyakit. Pencegahan terhadap kerusakan organ akibat perkembangan penyakit maupun akibat pengobatan perlu diperhatikan (Touma \& Gladman, 2017). Studi mengenai potensi interaksi obat pada pasien SLE masih sangat terbatas. Pengobatan berdasarkan manifestasi klinis yang muncul dari masing-masing individu penderita SLE, yang rentan menimbulkan terjadinya interaksi obat karena kompleks dan beragamnya obat yang diterima pasien SLE.

Pengobatan dan perawatan yang tepat dan benar sangat dibutuhkan oleh penderita SLE, yang bertujuan untuk mengatasi gejala dan induksi remisi serta mempertahankan remisi selama mungkin pada perkembangan penyakit. Pengobatan didasarkan pada manifestasi klinis yang muncul dari masingmasing individu penderita SLE, yang rentan menimbulkan terjadinya interaksi obat karena kompleks dan beragamnya obat yang diterima pasien SLE.

\section{METODE PENELITIAN}

Penelitian ini merupakan penelitian noneksperimental (observasional) dengan menggunakan rancangan deskriptif yang bersifat retrospektif. Penelitian dilakukan di sebuah rumah sakit di Denpasar terhadap data periode JanuariDesember 2019. Penelitian ini menggunakan teknik purposive sampling, sengan penetapan besar sample menggunakan rumus Slovin. Kriteria penelitian terdiri atas kriteria inklusi dan eksklusi.

\section{Kriteria Inklusi:}

a. Pasien dengan diagnosa SLE usia dewasa 17 tahun - 65 tahun

b. Pasien Rawat Jalan di rumah sakit tempat penelitian.

c. Data Rekam medis lengkap

Kriteria Ekslusi:

a. Pasien dalam keadaan hamil

b. Pasien menyusui

Penelitian ini menggunakan data sekunder yang dilakukan dengan cara mengumpulkan data melalui catatan rekam medis pasien SLE dan rekaman data pemakaian obat pada electronic prescribing pada sistem informasi elektronik yang menjalani rawat jalan di Instalasi Rawat Jalan. Penelitian ini telah mendapatkan persetujuan etik oleh Komite Etik Penelitian Fakultas Kedokteran Universitas Udayana dengan nomor: 1217/UN14.2.2.VII.14/LT/2020.

\section{HASIL DAN PEMBAHASAN}

Dalam penelitian jumlah populasi selama 1 tahun yaitu 410 pasien dan besar sampel yang digunakan menurut rumus slovin adalah 203 sampel. Adapun karakteristik pasien berdasarkan jenis kelamin dapat dilihat pada tabel 1 dan karakteristik berdasarkan usia dapat dilihat pada tabel 2 . 
Berdasarkan data pada tabel 1, diketahui bahwa perempuan memiliki persentase lebih besar untuk mengalami SLE. Hal ini sesuai dengan penelitian penelitian sebelumnya dimana prevalensi SLE pada perempuan lebih besar dari pada laki-laki (Cunha \& Gilek-Seibert, 2016; Touma \& Gladman, 2017). Estrogen berpotensi mempengaruhi subset seluler dari system imun melalui mekanisme pengaruh terhadap estrogen. Estrogen mempengaruhi antidouble-stranded DNA antibody dan produksi IgG, IgM oleh PBMCs. Selain itu estrogen juga meningkatkan reaktivasi antigen eksogen dan meningkatkan ekspresi autoantigen endogen, misalnya human endogenous retrovirus (HERV) yang secara molecular menyerupai antigen RNP yang meningkat pada pasien SLE. Estrogen juha memicu inflamasi sitemik dan menginduksi sel B activating factor dan IFN signature genes (Choi, Barber, Barber, Clarke, \& Fritzler, 2016).

Tabel.1 Profil Pasien SLE Berdasarkan Jenis Kelamin

\begin{tabular}{lcc}
\hline $\begin{array}{c}\text { Jenis } \\
\text { Kelamin }\end{array}$ & Jumlah & $\begin{array}{c}\text { Persentase } \\
(\%)\end{array}$ \\
\hline Laki-laki & 27 & 12,86 \\
Perempuan & 183 & 87,14 \\
\hline Jumlah & $\mathbf{2 1 0}$ & $\mathbf{1 0 0}$
\end{tabular}

Tabel 2. Profil Pasien SLE Berdasarkan Usia

\begin{tabular}{ccc}
\hline Usia (tahun) & Jumlah & $\begin{array}{c}\text { Persentase } \\
\text { (\%) }\end{array}$ \\
\hline $17-25$ & 61 & 29,05 \\
$26-35$ & 57 & 27,14 \\
$36-45$ & 49 & 23,33 \\
$46-55$ & 29 & 13,81 \\
$56-65$ & 14 & 6,67 \\
\hline Jumlah & $\mathbf{2 1 0}$ & $\mathbf{1 0 0}$ \\
\hline
\end{tabular}

Berdasarkan data pada Tabel 2, menunjukkan kesesuaian dengan pernyataan yang dikeluarkan oleh Perhimpunan Rematologi Indonesia bahwa rentang usia tertinggi penderita SLE adalah 21-30 tahun yaitu usia produktif dengan peningkatan jumlah produksi hormon estrogen pada perempuan. Pemendekan telomer juga mempengaruhi banyak terdeteksinya penyakit SLE pada rentang usia 22-55 tahun (Kementerian Kesehatan Republik Indonesia, 2017). Telomer adalah DNA-protein kompleks penutup ujung kromosom yang berfungsi untuk melindungi DNA dari kerusakan dan juga berperan penting dalam mempertahankan kestabilan kromosom dalam proses pembelahan sel. Pada rentang usia tersebut telomer mengalami pemendekan secara signifikan, sehingga menyebabkan pengurangan satu atau lebih nukleotida DNA limfosit yang berakibat limfosit mengalami kegagalan dalam mengenali antigen tubuh sendiri. Keadaan ini dapat menyebabkan seseorang semakin beresiko mengalami penyakit autoimun (Brinks et al., 2016; Perhimpunan Reumatologi Indonesia, 2019).

Tabel 3 Data distribusi pasien SLE berdasarkan manifestasi klinis

\begin{tabular}{clcc}
\hline No & Manifestasi klinis & $\begin{array}{c}\text { Jumlah } \\
\text { pasien }\end{array}$ & $\begin{array}{c}\text { Persentase } \\
\text { (\%) }\end{array}$ \\
\hline 1 & $\begin{array}{l}\text { Rheumatik } \\
\text { Arthritis }\end{array}$ & 186 & 88,6 \\
2 & $\begin{array}{l}\text { Nefrologi (Nefritic } \\
\text { syndrome) }\end{array}$ & 20 & 9,4 \\
3 & Neurologi & 2 & 1,0 \\
4 & Hematologi & 2 & 1,0 \\
\hline & Jumlah & $\mathbf{2 1 0}$ & $\mathbf{1 0 0}$ \\
\hline
\end{tabular}

Berdasarkan tabel 3 dapat diketahui bahwa SLE merupakan penyakit inflamasi autoimun heterogen kronis dengan etiologi yang belum diketahui, manifestasi klinis, perjalanan penyakit yang beragam serta melibatkan banyak organ berbeda, serta diikuti dengan adanya sebuah perjalanan klinis yang bervariasi (Kuhn et al., 2015). Penggunaan obat-obat penekan sistem imun dapat dilihat pada tabel 4. Penggunaan imunosupresan sangat membantu untuk mengurangi gejala yang timbul, mencegah kerusakan pada organ vital (paruparu atau ginjal) dan membantu mencapai remisi. Methylprednisolon dipilih sebagai terapi terbanyak diantara golongan imunosupresan lainnya disebabkan karena selain sebagai imunosupresan juga dapat digunakan sebagai anti inflamasi. Methylprednisolon merupakan glukokortikoid sintetik turunan dari prednisolon yang mempunyai efek kerja kebih kuat dari prednison dan dapat diberikan secara oral maupun intravena. Selain itu pemberian methylprednisolone lebih disukai karena lebih mudah dalam pengaturan dosisnya (Perhimpunan Reumatologi Indonesia, 2019; Touma \& Gladman, 2017).

Terapi antibiotik dengan jumlah peresepan terbanyak yaitu nistatin drop yaitu sebanyak $71,42 \%$ yang digunakan untuk pengobatan ulcus pada mukosa mulut, kemudian levofloxacin dan cefixime masing-masing sebanyak $14,29 \%$ (tabel 3 ). Pasien SLE memiliki kecenderungan untuk mudah mengalami infeksi, diantaranya infeksi saluran pernafasan, infeksi saluran kencing dan infeksi kulit, mukosa dan infeksi sistemik. Terdapat dua mekanisme yang dapat meningkatkan risiko infeksi 
pada pasien SLE yaitu: pertama faktor genetic yang mengakibatkan terjadinya immunodefisiensi, kedua perjalanan penyakit yang sudah mencapai immunopatologi akut. antibiotik merupakan salah satu terapi utama yang diberikan pada pasien SLE, dikarenakan penggunaan kortikosteroid sebagai imunosupresan dapat meningkatkan resiko terjadinya infeksi. (Barber \& Clarke, 2020; Sciascia, Cuadrado, \& Karim, 2013).

Tabel 4. Penggunaan Obat Penekan Sistem Imun

\begin{tabular}{|c|c|c|c|}
\hline No & $\begin{array}{c}\text { Obat } \\
\text { Imunosupresan }\end{array}$ & Jumlah & $\begin{array}{c}\text { Persentase } \\
\text { (\%) }\end{array}$ \\
\hline \multicolumn{4}{|c|}{$\begin{array}{r}\text { Oral } \\
\end{array}$} \\
\hline 1 & Methylprednisolon & 183 & 48,93 \\
\hline 2 & Azathioprin & 83 & 22,19 \\
\hline 3 & $\begin{array}{l}\text { Mikofenolat } \\
\text { sodium }\end{array}$ & 43 & 11,50 \\
\hline 4 & Hidroksiklorokuin & 29 & 7,75 \\
\hline 5 & Methotrexate & 22 & 5,88 \\
\hline \multirow[t]{2}{*}{6} & Siklosporin & 4 & 1,08 \\
\hline & Prednison & 5 & 1,34 \\
\hline 7 & $\begin{array}{l}\text { Mikofenolat } \\
\text { mofetil }\end{array}$ & 2 & 0,53 \\
\hline 9 & Leflunomid & 2 & 0,53 \\
\hline 10 & deksametason & 1 & 0,27 \\
\hline & Jumlah & 374 & 100 \\
\hline \multicolumn{4}{|c|}{ Topikal } \\
\hline 1 & $\begin{array}{l}\text { Desoksimetason } \\
\text { cream }\end{array}$ & 1 & 50 \\
\hline 2 & $\begin{array}{l}\text { Hidrokortison } \\
\text { cream }\end{array}$ & 1 & 50 \\
\hline & Jumlah & 2 & 100 \\
\hline
\end{tabular}

Terapi analgetik parasetamol diberikan karena efek samping yang ditimbulkan paling rendah diantara analgetik lain dalam mengatasi keluhan nyeri kepala, persendian maupun dalam menurunkan demam, jika dibandingkan dengan pemberian analgetik golongan NSAID yang dapat mengakibatkan perdarahan pada lambung karena mekanisme kerja NSAID yaitu menghambat produksi siklooksigenase-1 (COX-1) dan sikooksigenase-2 (COX-2). Penghambatan COX-1 menurunkan produksi prostaglandin yang melindungi lapisan gastrointestinal - track, penghambatan COX-2 memediasi produksi prostaglandin yang meringankan rasa nyeri dan inflamasi. Penggunaan parasetamol sebagai pilihan terapi dalam mengurangi rasa nyeri dan demam yaitu $88,46 \%$ sedangkan sisanya mendapatkan terapi golongan NSAID dan gabapentin (Pangalila dkk 2016).

Terdapat terapi lain yang digunakan oleh dokter untuk mengatasi penyakit penyerta atau komplikasi yang dialami pasien, progresivitas penyakit, atau untuk mengatasi efek samping yang timbul. Hipertensi pada SLE dapat disebabkan karena progresivitas penyakit itu sendiri atau karena efek samping penggunaan kortikosteroid. Preparat antihipertensi yang terdata pada penelitian ini yaitu beta blocker (bisoprolol, propanolol dan carvedilol), angiotensin II reseptor blockers (valsartan, irbesartan, kandesartan dan telmisartan), angiotensin converting enzyme inhibitors (captopril, ramipril), dan calcium channel blockers (amlodipin dan nifedipin). Manifestasi klinis dapat terjadi pada ginjal berupa edema seluruh tubuh yang dapat diatasi dengan penggunaan diuretik seperti furosemid dan spironolakton (Perhimpunan Reumatologi Indonesia, 2019).

\section{Tabel 5. Persentase Penggunaan Obat Antibiotik pada Pasien SLE}

\begin{tabular}{llcc}
\hline No & Antibiotika & Jumlah & $\begin{array}{c}\text { Persentase } \\
\text { (\%) }\end{array}$ \\
\hline \multicolumn{2}{c}{ Oral } \\
\hline 1 & Nistatin drop & 5 & 71,42 \\
2 & Cefixime & 1 & 14,29 \\
3 & Levofloxacin & 1 & 14,29 \\
\hline Jumlah & $\mathbf{7}$ & $\mathbf{1 0 0}$ \\
\hline \multicolumn{4}{c}{ Topikal } \\
\hline 1 & Na. Fusidat cream & $\mathbf{2}$ & $\mathbf{1 0 0}$ \\
\hline
\end{tabular}

Tabel 6. Persentase Penggunaan Obat Analgetika pada Pasien SLE

\begin{tabular}{llcc}
\hline No & Analgetika & Jumlah & $\begin{array}{c}\text { Persentase } \\
\text { (\%) }\end{array}$ \\
\hline 1 & Parasetamol & 23 & 88,46 \\
2 & Meloxicam & 2 & 7,69 \\
3 & Gabapentin & 1 & 3,85 \\
\hline Jumlah & $\mathbf{2 6}$ & $\mathbf{1 0 0}$ \\
\hline
\end{tabular}

Data penggunaan suplemen dapat dilihat pada Tabel 8. Terdapat suplemen kalsium (kalsium lactat dan $\mathrm{CaCO}_{3}$ ) yang diterima pasien, hal ini untuk mengatasi osteoporosis akibat penggunaan kortikosteroid, pemberian zat besi (oral dan intra vena ) dan asam folat untuk penanggulangan anemia (Perhimpunan Reumatologi Indonesia, 2019) Penggunaan obat-obatan yang bersifat gastroprotektif digunakan untuk mengatasi efek samping penggunaan imunosupresan. Jenis obat tersebut yaitu proton pump inhibitors (lansoprasol, omeprasol dan pantoprasol), pelindung mukosa lambung (sukralfat) dan penetral asam lambung (antasida) (Wardaniati dkk 2016). Terdapat beberapa golongan obat lain yang digunakan oleh pasien SLE (Tabel 9). Obat tersebut terdiri atas: domperidon, fenitoin, asam valproate, salbutamol, anti histamine (cetirizine dan CTM) dan juga dapat 
berperan sebagai anti inflamasi, obat anti depresi seperti amitriptyline, sertraline dan alprazolam. Terapi obat golongan lain ini diberikan sesuai dengan keluhan/gejala yang dirasakan pasien.

\section{Tabel 7. Persentase Penggunaan Obat Hipertensi pada Pasien SLE}

\begin{tabular}{clcc}
\hline No & \multicolumn{1}{c}{ Obat Hipertensi } & Jumlah & $\begin{array}{c}\text { Persentase } \\
\text { (\%) }\end{array}$ \\
\hline 1 & Valsartan & 34 & 22,22 \\
2 & Amlodipin & 33 & 21,57 \\
3 & Ramipril & 19 & 12,42 \\
4 & Kaptopril & 18 & 11,76 \\
5 & Kandesartan & 11 & 7,19 \\
6 & Bisoprolol & 9 & 5,88 \\
7 & Diltiazem & 5 & 3,27 \\
8 & Karvedilol & 5 & 3,27 \\
9 & Spironolacton & 5 & 3,27 \\
10 & Furosemida & 4 & 2,62 \\
11 & Irbesartan & 4 & 2,62 \\
12 & Telmisartan & 2 & 1,31 \\
13 & Nifedipin & 1 & 0,65 \\
14 & Klonidin & 1 & 0,65 \\
15 & Lisinopril & 1 & 0,65 \\
16 & Propanolol & 1 & 0,65 \\
\hline Jumlah & $\mathbf{1 5 3}$ & $\mathbf{1 0 0}$ \\
\hline
\end{tabular}

Tabel 8. Persentase Penggunaan Vitamin dan Mineral

\begin{tabular}{clcc}
\hline No & Vitamin dan Mineral & Jumlah & $\begin{array}{c}\text { Persentase } \\
\text { (\%) }\end{array}$ \\
\hline 1 & Kalsium lactat & 51 & 52,58 \\
2 & Asam folat & 31 & 31,96 \\
3 & Ferro sulfat & 4 & 4,12 \\
4 & Vitamin b komplex & 4 & 4,12 \\
5 & Kalium klorida & 3 & 3,10 \\
6 & Eritropoetin alfa & 2 & 2,06 \\
7 & Kalsium karbonat & 1 & 1,03 \\
8 & Rhinofer & 1 & 1,03 \\
\hline Jumlah & $\mathbf{9 7}$ & $\mathbf{1 0 0}$ \\
\hline
\end{tabular}

Data potensi interaksi obat dapat dilihat pada tabel 10. Potensi interaksi obat ditemukan hampir di setiap terapi yang diberikan kepada pasien SLE. Potensi interaksi yang terjadi dikelompokkan menjadi tiga yaitu mayor, sedang, dan minor. Potensi interaksi mayor terbanyak yaitu kombinasi amlodipine dan simvastatin sebesar 23,81\% (10 pasien). Penggunaan kombinasi obat ini perlu diwaspadai. Simvastatin dimetabolisme oleh sitokrom p-450 isoenzim CYP3A4, dan sangat sensitive terhadap dampak dari pemberian obatobat yang menghambat CYP3A4. Amlodipin merupakan salah satu penghambat CYP3A4 lemah.
Penggunaan kedua obat ini secara bersamaan dapat meningkatkan kadar simvastatin dalam darah sehingga dapat menyebabkan resiko efek samping seperti kerusakan hati dan rhabdomyolisis. Penyesuaian dosis perlu dilakukan jika kedua obat ini harus digunakan bersamaan (Kanukula, Esam, Sundström, Rodgers, \& Salam, 2019).

Tabel 9. Persentase Penggunaan Obat Lainnya

\begin{tabular}{|c|c|c|c|}
\hline No & Nama Obat & Jumlah & $\begin{array}{c}\text { Persentase } \\
\text { (\%) }\end{array}$ \\
\hline \multicolumn{4}{|c|}{ Antasida - Anti Ulcer } \\
\hline 1 & Lansoprazol & 30 & 21,13 \\
\hline 2 & Antasida & 2 & 1,41 \\
\hline 3 & Omeprazole & 2 & 1,41 \\
\hline 4 & Ranitidin & 1 & 0,70 \\
\hline \multicolumn{4}{|c|}{ Antikoagulan } \\
\hline 1 & Asetosal & 29 & 20,42 \\
\hline 2 & Klopidogrel & 1 & 0,70 \\
\hline 3 & Warfarin & 1 & 0,70 \\
\hline \multicolumn{4}{|c|}{ Anti-Histamin } \\
\hline 1 & Setirizine & 6 & 4,23 \\
\hline 2 & Ctm & 2 & 1,41 \\
\hline \multicolumn{4}{|c|}{ Anti Epilepsi } \\
\hline & Asam valproat & 2 & 1,41 \\
\hline & Fenitoin & 2 & 1,41 \\
\hline \multicolumn{4}{|c|}{ Anti depresan } \\
\hline 1 & Amitriptylin & 1 & 0,70 \\
\hline 2 & Alprazolam & 1 & 0,70 \\
\hline 3 & Sertralin & 1 & 0,70 \\
\hline \multicolumn{4}{|c|}{ Anti-Hiperuricemia } \\
\hline 1 & Alopurinol & 8 & 5,63 \\
\hline \multicolumn{4}{|c|}{ Anti-Hiperlipidemia } \\
\hline 1 & Simvastatin & 36 & 25,35 \\
\hline \multicolumn{4}{|c|}{ Hipertiroid } \\
\hline 1 & Tiamazol & 1 & 0,70 \\
\hline \multicolumn{4}{|c|}{ Anti-Emetik } \\
\hline 1 & Domperidon & 3 & 2,11 \\
\hline \multicolumn{4}{|c|}{ Anti-Diabetik } \\
\hline 1 & Metformin & 1 & 0,70 \\
\hline \multicolumn{4}{|c|}{ Obat Sesak } \\
\hline 1 & Salbutamol & 1 & 0,70 \\
\hline \multicolumn{4}{|c|}{ Vasodilatasi } \\
\hline 1 & Isosorbid Dinitrat & 1 & 0,70 \\
\hline \multicolumn{4}{|c|}{ Lain-lain } \\
\hline 1 & Asam ursodeoxycolat & 3 & 2,11 \\
\hline 2 & Colchisin & 1 & 0,70 \\
\hline 3 & Donenzepil & 1 & 0,70 \\
\hline 4 & lamivudin & 1 & 0,70 \\
\hline 5 & Cendo lyters eye drop & 1 & 0,70 \\
\hline 6 & Cendo xitrol eye drop & 1 & 0,70 \\
\hline 7 & $\begin{array}{l}\text { Fluometholon eye } \\
\text { drop }\end{array}$ & 1 & 0,70 \\
\hline 8 & Ketokonazol cream & 1 & 0,70 \\
\hline & Jumlah & 142 & 100 \\
\hline
\end{tabular}


Tabel 10. Potensi Interaksi Obat Pada Pasien SLE

\begin{tabular}{clcc}
\hline No & $\begin{array}{c}\text { Potensi Interaksi } \\
\text { yang terjadi }\end{array}$ & Jumlah & $\begin{array}{c}\text { Persentase } \\
\text { (\%) }\end{array}$ \\
\hline 1 & Mayor & 30 & 14,3 \\
2 & Sedang & 100 & 47,6 \\
3 & Minor & 1 & 0,5 \\
4 & Tidak ada interaksi & 79 & 37,6 \\
\hline & Jumlah & $\mathbf{2 1 0}$ & $\mathbf{1 0 0}$ \\
\hline
\end{tabular}

Potensi interaksi sedang diidentifikasi paling banyak dalam pemberian terapi obat pada pasien SLE yaitu kepada 100 orang pasien Penyesuaian dosis, pemisahan waktu penggunaan dapat digunakan untuk menekan timbulnya potensi interaksi, dan monitoring kemungkinan terjadinya hipertensi harus terus dipantau Potensi interaksi minor merupakan potensi interaksi yang paling sedikit ditemukan. Kombinasi antara obat methylprednisolone dan valsartan yaitu sebanyak 29 peresepan. Kombinasi penggunaan methylprednisolon dan valsartan secara bersamaan dapat menurunkan efek dari valsartan dalam menurunkan tekanan darah, tetapi hal ini terjadi jika pemakaian methylprednisolon lebih dari 1 minggu yang menyebabkan retensi garam dan air yang mengakibatkan penurunan GFR dan fungsi ginjal (American Pharmacist Ascotiation, 2017). Kombinasi yang menimbulkan interaksi minor yaitu antara amlodipine dan captopril. Pada tingkat keparahan minor efek yang timbul biasanya ringan atau tidak timbul sama sekali dan tidak mempengaruhi outcome terapy (Tian et al., 2018).

\section{SIMPULAN}

Berdasarkan hasil penelitian dapat disimpulkan yaitu, penggunaan obat pada pasien SLE di Instalasi Rawat Jalan di sebuah rumah sakit di Denpasar terdiri atas obat golongan imunosupresan, antibiotik, analgetik dan terapi lain sesuai komorbiditas pasien. Jenis imunosupresan yang digunakan yaitu methylprednisolone (48,93\%), azatriopin (22,19\%) dan mikofenolat mofetil $(11,50 \%)$. Jenis antibiotik yang digunakan yaitu nistatin $(71,42 \%)$, levofloxacin dan cefixim masing masing $14,29 \%$. Jenis analgetik yang digunakan yaitu parasetamol dengan penggunaan terbanyak yaitu $88,46 \%$ kemudian meloxicam $(7,69 \%)$ dan gabapentin $(3,85 \%)$. Potensi interaksi obat yang terjadi yaitu interaksi mayor sebanyak 14,3\%, interaksi sedang sebanyak $47,6 \%$, interaksi minor sebesar $0,5 \%$ dan tidak ditemukannya adanya potensi interaksi obat $37,6 \%$.

\section{DAFTAR PUSTAKA}

American Pharmacist Ascotiation. (2017). Drug Information Handbook: A Clinically Relevant Resource for All Healthcare Professionals. United State: Wolters Kluwer.

Barber, M. R. W., \& Clarke, A. E. (2020). Systemic lupus erythematosus and risk of infection. Expert Review of Clinical Immunology, 16(5), 527-538.

Brinks, R., Hoyer, A., Weber, S., Fischer-Betz, R., Sander, O., Richter, J. G., ... Schneider, M. (2016). Age-specific and sex-specific incidence of systemic lupus erythematosus: an estimate from cross-sectional claims data of 2.3 million people in the German statutory health insurance 2002. Lupus Science \& Medicine, 3(1), e000181.

Choi, M. Y., Barber, M. R. W., Barber, C. E. H., Clarke, A. E., \& Fritzler, M. J. (2016). Preventing the development of SLE: identifying risk factors and proposing pathways for clinical care. Lupus, 25(8), 838-849.

Cunha, J. S., \& Gilek-Seibert, K. (2016). Systemic lupus erythematosus: A review of the clinical approach to diagnosis and update on current targeted therapies. Rhode Island Medical Journal, 99(12), 23.

Kamal, M. A., \& Jusko, W. J. (2014). Interactions of Prednisolone and Other Immunosuppressants Used in Dual Treatment of Systemic Lupus Erythematosus in Lymphocyte Proliferation Assays. Journal of Clinical Pharmacology, 44(9), 1034-1045.

https://doi.org/10.1177/0091270004267808.I nteractions

Kanukula, R., Esam, H., Sundström, J., Rodgers, A., \& Salam, A. (2019). Does Co-administration of Antihypertensive Drugs and Statins Alter Their Efficacy and Safety? A Systematic Review and 
Meta-analysis of Randomized Controlled Trials. Journal of Cardiovascular Pharmacology, 73(6), 352-358.

Kementerian Kesehatan Republik Indonesia. (2017). Situasi Lupus di Indonesia. Pusat Data dan Informasi Kementerian Kesehatan Republik Indonesia.

Kuhn, A., Bonsmann, G., Anders, H.-J., Herzer, P., Tenbrock, K., \& Schneider, M. (2015). The diagnosis and treatment of systemic lupus erythematosus. Deutsches Ärzteblatt International, 112(25), 423.

Perhimpunan Reumatologi Indonesia. (2019). Diagnosis dan Pengelolaan Lupus Eritematosus Sistemik. Jakarta: Perhimpunan Reumatologi Indonesia.
Sciascia, S., Cuadrado, M. J., \& Karim, M. Y. (2013). Management of infection in systemic lupus erythematosus. Best Practice \& Research Clinical Rheumatology, 27(3), 377-389.

Tian, J., Luo, Y., Wu, H., Long, H., Zhao, M., \& Lu, Q. (2018). Risk of adverse events from different drugs for SLE : a systematic review and network meta-analysis. 1-9. https://doi.org/10.1136/lupus-2017-000253

Touma, Z., \& Gladman, D. D. (2017). Current and future therapies for SLE: obstacles and recommendations for the development of novel treatments. Lupus Science and Medicine, 4, 1-11. https://doi.org/10.1136/lupus-2017000239. 